\title{
Identifying Randomly Amplified Polymorphic DNA (RAPD) Markers Linked to Major Genes for Common Bacterial Blight Resistance in Tepary Bean
}

\author{
Soon O. Park, Dermot P. Coyne, Atilla Dursun, and Geunhwa Jung ${ }^{1}$ \\ Department of Horticulture, University of Nebraska, Lincoln, NE 68583-0724
}

\begin{abstract}
AdDitional IndeX words. Phaseolus acutifolius, Phaseolus vulgaris, Xanthomonas campestris pv. phaseoli races, major dominant genes, bulked segregant analysis, coupling phase linkage

ABsTRaCT. Common bacterial blight (CBB), incited by Xanthomonas campestris pv. phaseoli (Xcp), is an important seedtransmitted disease of common bean (Phaseolus vulgaris L.). Tepary bean (Phaseolus acutifolius A. Gray) has high resistance to $X c p$. The objective of this study was to identify RAPD markers linked to genes controlling resistance to three isolates of $X c p$ using bulked segregant analysis in an $F_{2}$ population from the tepary bean cross CIAT-G40005 (resistant to $X c p$ ) $X$ Nebr.\#4B (susceptible to $X c p$ ). Twelve RAPD markers were mapped in a coupling-phase linkage with three genes for resistance to $X c p$. The linkage group spanned a distance of $19.2 \mathrm{cM}$. A marker $\mathrm{L} 7_{750}$ was linked to the genes for resistance to $X c p$ strains EK-11 and LB-2 at $8.4 \mathrm{cM}$ and $2.4 \mathrm{cM}$, respectively. Markers U10 ${ }_{400}$ and Y14 ${ }_{600}$ were detected as flanking markers for the resistance gene to $X c p$ strain $\mathrm{SC}-4 \mathrm{~A}$ at $2.4 \mathrm{cM}$ and $7.2 \mathrm{cM}$, respectively. The symbols $X c p-1, X c p-2$, and $X c p-3$ were assigned for the genes for resistance to $X c p$ strains EK-11, LB-2, and SC-4A, respectively. RAPD markers linked to the genes for resistance to $X c p$ could be used for transferring all of the resistance genes from $P$. acutifolius to a susceptible $\boldsymbol{P}$. vulgaris cultivar.
\end{abstract}

Common bacterial blight (CBB), incited by Xanthomonas campestris pv. phaseoli $(X c p)$, is an important seed-transmitted disease of common bean [Phaseolus vulgaris $\mathrm{L} .(P v)$ ], resulting in reduced yields and seed quality (Saettler, 1989). Environmental conditions, such as high temperature, high humidity, and frequent rains, and susceptible cultivars provide conditions favorable to disease spread (Saettler, 1989). Management practices such as using certified bacteria-free seed, rotation, weed control, and ploughing down of infested straw reduce losses from the disease (Schuster and Coyne, 1981). Common bean cultivars resistant to $X c p$ provide the most effective and economical strategy to control this disease (Schwartz and Galvez, 1981).

Breeding common beans resistant to $X c p$ has been conducted for several decades and $P v$ lines and cultivars with moderately high levels of resistance have been developed (Coyne and Schuster, 1983; McElroy, 1985; Saettler, 1989; Scott and Michaels, 1992; Singh et al., 1996; Yoshii et al., 1978). Tepary bean [Phaseolus acutifolius A. Gray $(\mathrm{Pa})$ ] is highly resistant to $\mathrm{Xcp}$ (Drijfhout and Blok, 1987; Freytag, 1989; Honma, 1956; McElroy, 1985; Zaiter et al., 1989), while most commercial cultivars of common bean are highly susceptible. Drijfhout and Blok (1987) reported that one major dominant gene was involved in controlling leaf and pod resistance reactions to $X c p$ in tepary bean. However, McElroy (1985) reported a quantitative pattern of inheritance of resistance in an interspecific cross of common bean $x$ tepary bean with three genes involved in controlling resistance to $X c p$. One gene had a predominant effect on resistance. XAN-161 and XAN-159 possess different genes for resistance to $X c p$ even though derived from Pa PI 319443 (Kolkman and Michaels, 1994). A major gene for

Received for publication 29 May 1997. Accepted for publication 17 Nov. 1997 Nebraska Agricultural Research Division Journal Series paper 11878. Research was conducted under projects 20-036 and 20-042. We acknowledge financial support from the Title XII Bean/Cowpea CRSP (AID contract DNA-1310-G-SS6008-00). We also appreciate assistance of technicians Lisa Sutton and James Reiser. The cost of publishing this paper was defrayed in part by the payment of pagc charges. Under postal regulations, this paper therefore must be hereby marked advertisement solely to indicate this fact.

Current address: Dept. of Horticulture, Univ. of Wisconsin, Madison, WI 53706 resistance to $X c p$ was found in navy bean OAC 88-1 derived from $\mathrm{Pa}$ PI 440795; it differed from that found in the lines XAN-159 and XAN-161 [Centro Internacional de Agricultura Tropical (CIAT)] derived from $P a$ PI 319443 (Michaels, 1992). Honma (1956) also reported a quantitative inheritance pattern for the reaction to $X c p$ in a $P v \times P a$ cross. Because of limited investigations in the past, additional information on the inheritance of the reaction to $X c p$ in tepary bean germplasm is needed. In $P v$, the reaction to $X c p$ is quantitatively inherited (Aggour and Coyne, 1989; Arnaud-Santana et al., 1994) and QTLs for resistance to $X_{c} p$ have been mapped (Jung et al., 1996, 1997; Miklas et al., 1996; Nodari et al., 1993).

Bulked segregant analysis (BSA), developed by Michelmore et al. (1991), is an efficient method to rapidly identify markers linked to a specific gene using bulked DNA from $\mathrm{F}_{2}$ plants. This technique has been used to tag genes for rust resistance in common bean (Haley et al., 1993; Miklas et al., 1993; Park et al., 1997).

It is important to transfer more genes for resistance to $X c p$ from $P a$ to $P v$ to increase the level of resistance in all plant parts to $X c p$ in $P v$ cultivars/lines in order to obtain $X c p$ free seed. The level of resistance to $X c p$ in the much used breeding lines GN Nebraska \#1 sel. 27 (Coyne and Schuster, 1983) and XAN-159 (CIAT) (McElroy, 1985) needs to be improved. Molecular markers can be used to facilitate pyramiding of different genes for resistance to a pathogen, especially if epistasis is present, to develop more durable resistance. Tagging a major gene for resistance to $X_{c p}$ in a tepary bean cross has not been previously reported. The objective of this study was to identify RAPD markers linked to genes controlling resistance to three isolates of $X c p$ using bulked segregant analysis in an $\mathrm{F}_{2}$ population from the tepary bean cross CIAT-G40005 [resistant to $X c p(\mathrm{R})$ ] $\times$ Nebr.\#4B [susceptible to $X c p(\mathrm{~S})$ ].

\section{Materials and Methods}

Plant materials. The tepary bean cross 'CIAT-G40005' (CIAT, Cali, Colombia) (R) $x$ tepary 'Nebr.\#4B'(S) was made by M.F. Mohamed (Univ. of Assiut, Egypt) in 1992 while at Univ. of Nebraska, Lincoln. Clay pots of the parental lines and $77 F_{2}$ plants derived from the above cross were grown in 1993, and $28 F_{3}$ 
families ( 21 to 24 plants per $F_{3}$ ) from randomly selected $F_{2}$ plants were grown in 1994 in the greenhouse, Lincoln, to study the inheritance of the reaction to three strains of Xcp (Dursun, 1994). Two plants were planted in each $15-\mathrm{cm}$ pot. A nutrient solution containing $200 \mathrm{mg} \cdot \mathrm{L}^{-1} 20 \mathrm{~N}-10 \mathrm{P}-20 \mathrm{~K}$ fertilizer was applied every week. Pesticides were applied weekly to control white flies. The approximate greenhouse day/night temperatures were $27 \pm 2{ }^{\circ} \mathrm{C} /$ $20 \pm 2{ }^{\circ} \mathrm{C}$ and $28 \pm 3{ }^{\circ} \mathrm{C} / 21 \pm 3{ }^{\circ} \mathrm{C}$ for $\mathrm{F}_{2}$ and $\mathrm{F}_{3}$ experiments, respectively. The natural day/night lengths were $\approx 13 / 11 \mathrm{~h}$ and $14 /$ $10 \mathrm{~h}$ for $\mathrm{F}_{2}$ and $\mathrm{F}_{3}$ experiments, respectively.

Inoculatron. Three $X c p$ strains, EK-11, LB-2, and SC-4A, isolated from common beans in Nebraska (source: A.K. Vidaver, Dept. of Plant Pathology, Univ. of Nebraska, Lincoln) were used. These strains have been used previously in genetic and breeding studies in Nebraska. The strains were cultured on MXP medium (Claflin et al., 1987) for 48 to $72 \mathrm{~h}$ at $27^{\circ} \mathrm{C}$ under dark conditions and then transferred to $25 \mathrm{~mL}$ of $0.01 \mathrm{M}$ potassium phosphate buffer (pH7.1) and diluted to read 0.1 on a spectrophotometer (Spectronic 20; Bausch and Lomb, Rochester, N.Y.) at $640 \mathrm{~nm}$. A final concentration of $10^{8}$ colony-forming units (CFU) $/ \mathrm{mL}$ of each $X c p$ strain was prepared for inoculations by adding a measured bacterial suspension to potassium phosphate buffer. Inoculation was conducted within 30 min after the bacterial suspensions were prepared. The first fully expanded trifoliolate leaves of each $\mathrm{F}_{2}$ and $\mathrm{F}_{3}$ plants were inoculated with $X c p$ strains EK-11, LB-2, and SC4A using the multiple needle method $21 \mathrm{~d}$ after planting (Andrus, 1948). A potassium phosphate buffered solution was used as a control for leaf inoculations. Small spots of different acrylic paint colors were used to mark trifoliolate leaves randomly for use in inoculation with the three $X c p$ strains. The percentage of the inoculated leaf area showing disease symptoms of necrosis, watersoaking, and chlorosis and no symptoms were recorded for each plant $14 \mathrm{~d}$ after inoculation.

Bulked SEgregant analysis and RaPd. Noninoculated fully expanded trifoliolate leaves of the parents and $77 \mathrm{~F}_{2}$ plants from the tepary bean cross were collected at $28 \mathrm{~d}$ after planting. Total genomic DNA was extracted from lyophilized leaf tissue using the method of Skroch and Nienhuis (1995). A total of 602 primers was used for the RAPD analysis (Williams et al., 1990). Five-hundred and forty RAPD primers were obtained from Operon Technologies (Alameda, Calif.) and sixty-two RAPD primers were obtained from the Univ. of British Columbia (Vancouver, B.C.). Polymerase chain reactions (PCRs) were performed in an air thermalcycler (model 1605; Idaho Technology, Idaho Falls) in thin-walled glass capillary tubes. PCR protocols and the composition of the final volume of reactants were similar to those described by Skroch and Nienhuis (1995).

Three different separate bulked DNAs pairs were prepared from equal volumes of standardized DNA from eight homozygote resistant and eight homozygote susceptible $F_{2}$ plants selected based on $\mathrm{F}_{3}$ phenotypic data for each of the reactions to $X c p$ strains EK-11, LB-2, and SC-4A, respectively. Eight homozygote $F_{2}$ plants were used to develop bulked DNA because of the low number $\mathrm{F}_{3}$ families grown, which limited the detection of homozygous $\mathrm{F}_{2}$ plants. Only $28 \mathrm{~F}_{3}$ families ( 21 to 24 plants per $\mathrm{F}_{3}$ ) derived from the $77 \mathrm{~F}_{2}$ plants were inoculated with $3 X c p$ strains to confirm the hypothesis of a different major dominant gene for resistance to each of the $X c p$ strains. Only $28 \mathrm{~F}_{3}$ families were selected bccausc there was only space for $\approx 340$ pots in the greenhouse and some $F_{3}$ families did not have enough seeds.

The 602 primers were used to screen simultaneously between resistant and susceptible bulked DNAs and between the two parental lines. Forty-seven primers generated marker polymor- phisms between resistant and susceptible bulked DNAs and were tested subsequently on the eight individual homozygote resistant and eight individual susceptible $F_{2}$ plants used in the bulks. Twelve primers produced markers that were present in each of the eight homozygote resistant plants and absent in each of the eight homozygote susceptible plants. These 12 primers were then tested on the $\mathrm{F}_{2}$ segregating population.

Size markers from a 100-base pair ladder (Gibco BRL) were used to measure the locations of RAPD markers on the agarose gels. Marker size was determined to the nearest 50 base pairs based on the migration distance in comparison to size markers. The name of each RAPD marker is derived from the letter identifying the Operon kit, the Operon primer number, and the approximate length of the marker (Jung et al., 1996).

Statistical analysis. No symptoms $(0 \%)$ on the inoculated leaf area were classified as resistant plants, whereas disease symptoms $(1 \% \geq 11 \%)$ of necrosis and chlorosis on the inoculated leaf area were classified as susceptible plants. Bimodal distributions of resistant and susceptible plants were observed in the $F_{2}$ plants inoculated with each $X c p$ strain (Table 1). A goodness-offit to a 3:1 ratio of resistant to susceptible $F_{2}$ plants to each of three $X c p$ strains was then tested using a chi-square. A goodness of fit to a 1:2:1 segregation of nonsegregating for resistance, segregating, and nonsegregating for susceptibility to each of $3 X c p$ strains in 28 $F_{3}$ families ( 21 to 24 plants per $F_{3}$ ) derived from randomly selected $\mathrm{F}_{2}$ plants of the cross was tested using the chi-square to confirm the hypothesis of a major dominant gene for resistance to the $X c p$ strains. A goodness of fit to a 9:3:3:1 segregation of different combinations of reactions of $\mathrm{F}_{2}$ plants of the cross was tested using the chi-square test.

The $F_{2}$ plant segregation for each of the 12 markers identified by presence and absence of RAPD amplification was tested for goodness of fit to 3:1 ratio using a chi-square test. The segregation analysis of the 12 markers and 3 different loci for resistance to $X c p$ was performed on the data for $77 \mathrm{~F}_{2}$ plants using MAPMAKER Macintosh version 2.0 (Lander et al., 1987). The logarithm of odds (LOD) score of 3.0 was used as a linkage threshold with 0.3 as the maximum recombination fraction for linkage groups. Map distances (cM) between ordered loci of marker and gene were calculated using recombination fractions and Kosambi mapping function (Kosambi, 1944).

\section{Results and Discussion}

The InHeritance OF THE REACTION TO DIFFERENT $X c p$ STRAINS. All plants of Nebr.\#4B were susceptible to $X c p$, with typical common blight symptoms of necrosis and chlorosis on the inoculated leaves (Table 1). CIAT-G40005 was resistant to $X c p$ and showed no disease symptoms on the inoculated leaves of all plants (Table 1). Bimodal distributions for number of plants showing resistance (no symptoms) and susceptibility ( $>11 \%$ with common blight symptoms) to each $X c p$ strain were observed in the $\mathrm{F}_{2}$ (Table 1). No plants were observed in the class $1 \%$ to $10 \%$ of inoculated leaf area with common blight symptoms except for a few plants inoculated with isolate SC-4A. A goodness of fit to a 3:1 ratio of numbers of resistant to susceptible plants to each of three $X c p$ strains, respectively, was observed (Table 1). It was hypothesized that a single major gene primarily controlled resistance to each of these three $X c p$ strains. The hypothesis of a major dominant gene for resistance to each $X c p$ strain was confirmed in the $\mathrm{F}_{3}$ based on a satisfactory fit to a 1:2:1 ratio of families nonsegregating for resistance, segregating for resistance and susceptibility, and nonsegregating for susceptibility (Table 2). 
Recombinants resistant to only one $X c p$ strain and susceptible to another strain were observed for each of the three pairs of strains EK-11 and LB-2, EK-11 and SC-4A, and LB-2 and SC-4A in the $F_{2}$ generation of the cross (Table 3 ). In addition, recombinants resistant to one strain and susceptible to the other two strains were detected as follows: three recombinants resistant to EK-11 and susceptible to LB-2 and SC-4A, one recombinant resistant to SC$4 \mathrm{~A}$ and susceptible to EK-11 and LB-2, and no recombinants resistant to LB-2 and susceptible to EK-11 and SC-4A. A double crossover is necessary to detect the latter. This indicated that different genes controlled the reaction to each $X c p$ strain. Coupling linkage was detected between the genes controlling the reactions to each of three $X c p$ strains (Table 3). Freytag (1989) first reported that three different major dominant genes, in coupling phase linkage, controlled resistance to a different $X c p$ isolate in each of two tepary crosses. He did not confirm his hypothesis using $F_{3}$ progeny. It is not known if the resistance genes found here are similar to those reported by Freytag. An allelic test and inoculation with the same Xcp isolates should be conducted to determine if the same or different genes are involved.

IDENTIFYING RAPD MARKERS LINKED TO GENES FOR RESISTANCE TO Xcp. A total of 602 primers were used for the RAPD analysis of resistant and susceptible bulks along with the two parental lines. Fifty-eight RAPD markers were polymorphic for the resistant and susceptible bulked DNAs. All 58 displayed an amplified DNA fragment in resistant bulked DNAs that was absent in susceptible bulked DNAs. An example of a marker $\mathrm{U} 10_{400}$ is shown in Fig. 1. Only 12 of the 58 markers were always present in 8 homozygote resistant individual plants and always absent in 8 homozygote susceptible individual plants. The other 46 markers were present in $<4$ of the 8 homozygote resistant individual plants. Thus, the markers were considered false positives, suggesting that the markers were not linked to the genes for resistance to $X c p$. The 12 markers produced from the 12 primers segregated in $77 \mathrm{~F}_{2}$ plants.

Table 1. Chi-square tests for a 3:1 segregation of resistant and susceptible plants in an $\mathrm{F}_{2}$ tepary bean cross CIAT-G40005 [resistant to Xanthomonas campestris pv. phaseoli $\left.\left(X_{c p}\right)\right] \times$ Nebr.\#4B (susceptible to $X_{c p}$ ) for reactions to three strains of $X_{c p}$.

\begin{tabular}{|c|c|c|c|c|c|c|c|c|c|c|}
\hline \multirow{3}{*}{$\begin{array}{l}\text { Parent } \\
\text { or cross }\end{array}$} & \multirow{3}{*}{$\begin{array}{c}X c p \\
\operatorname{strain}^{7}\end{array}$} & & & & \multicolumn{4}{|c|}{$\mathrm{F}_{2}$ plants (no.) } & \multirow[b]{3}{*}{$\chi^{2}$} & \multirow[b]{3}{*}{$P$} \\
\hline & & \multicolumn{3}{|c|}{ Leaf area symptoms (\%) } & \multicolumn{2}{|c|}{ Observed } & \multicolumn{2}{|c|}{ Expected } & & \\
\hline & & 0 & $1-10$ & $>11$ & $\mathrm{R}^{\mathrm{y}}$ & $S^{x}$ & $\mathrm{R}$ & $\bar{S}$ & & \\
\hline \multirow[t]{3}{*}{$\overline{S P^{w}}$} & $\mathrm{~A}$ & & 2 & 13 & & & & & & \\
\hline & B & & 1 & 15 & & & & & & \\
\hline & $\mathrm{C}$ & & 1 & 15 & & & & & & \\
\hline \multirow[t]{3}{*}{$\mathrm{RP}^{\mathrm{v}}$} & A & 16 & & & & & & & & \\
\hline & B & 16 & & & & & & & & \\
\hline & $\mathrm{C}$ & 16 & & & & & & & & \\
\hline \multirow[t]{3}{*}{$\mathrm{F}_{2}$} & A & 53 & & 24 & 53 & 24 & 58 & 19 & 1.25 & 0.26 \\
\hline & B & 50 & & 27 & 50 & 27 & 58 & 19 & 3.64 & 0.06 \\
\hline & $\mathrm{C}$ & 51 & 5 & 21 & 51 & 26 & 58 & 19 & 2.71 & 0.10 \\
\hline
\end{tabular}

2Strain code: $\mathrm{A}=\mathrm{EK}-11, \mathrm{~B}=\mathrm{LB}-2, \mathrm{C}=\mathrm{SC}-4 \mathrm{~A}$.

${ }^{\mathrm{y}} \mathrm{R}=$ resistant, $0 \%$ of leaf area symptoms.

${ }^{\mathrm{x}} \mathrm{S}=$ susceptible, $1 \leq 11 \%$ of leaf area symptoms.

${ }^{w} S P=$ susceptible parent, Nebr.\#4B.

${ }^{v} \mathrm{RP}=$ resistant parent, CIAT-G40005.

Table 2. Chi-square tests for a 1:2:1 segregation of nonsegregating for resistance (R), segregating for resistance and susceptibility (S), and nonsegregating for susceptibility in $28 \mathrm{~F}_{3}$ families $\left(21\right.$ 10 24 plants per $\mathrm{F}_{3}$ ) derived from the tepary bean cross CIAT-G40005 [resistant to Xanthomonas campestris pv. phaseoli $(X c p)] \times$ Nebr.\#4B (susceptible to Xcp) for reactions to three strains of $X c p$.

\begin{tabular}{|c|c|c|c|c|c|}
\hline \multirow[b]{2}{*}{$\begin{array}{l}X c p \\
\text { strain }\end{array}$} & \multicolumn{3}{|c|}{$\mathrm{F}_{3}$ families (no.) } & \multirow[b]{2}{*}{$\chi^{2}$} & \multirow[b]{2}{*}{$P$} \\
\hline & $\begin{array}{c}\text { Nonsegregating } \\
\text { for } \mathrm{R}\end{array}$ & Segregating & $\begin{array}{l}\text { Nonsegregating } \\
\text { for } \mathrm{S}\end{array}$ & & \\
\hline$\overline{\text { EK-11 }}$ & 10 & 10 & 8 & 2.57 & 0.28 \\
\hline LB-2 & 9 & 9 & 10 & 3.65 & 0.16 \\
\hline SC-4A & 8 & 11 & 9 & 1.35 & 0.51 \\
\hline
\end{tabular}

Table 3. Chi-square tests for segregation of different combinations of reactions of $\mathrm{F}_{2}$ plants from the tepary bean cross CIAT-640005 [resistant to Xanthomonas campestris pv. phaseoli $(X c p)] \times$ Nebr.\#4B (susceptible to Xcp) to three strains of Xcp.

\begin{tabular}{|c|c|c|c|c|c|c|c|}
\hline \multirow{2}{*}{$\begin{array}{l}X c p \\
\text { strain } \\
\text { codes }^{z}\end{array}$} & \multicolumn{4}{|c|}{$\mathrm{F}_{2}$ plants $^{y}$ (no.) } & \multirow{2}{*}{$\begin{array}{c}\text { Expected } \\
\text { ratio }\end{array}$} & \multirow[b]{2}{*}{$\chi^{2}$} & \multirow[b]{2}{*}{$P$} \\
\hline & $\mathrm{RR}$ & RS & SR & SS & & & \\
\hline$\overline{\mathrm{A}-\mathrm{B}}$ & 49 & 4 & 1 & 23 & $9: 3: 3: 1$ & 89.60 & $<0.001$ \\
\hline $\mathrm{A}-\mathrm{C}$ & 49 & 4 & 2 & 22 & $9: 3: 3: 1$ & 80.45 & $<0.001$ \\
\hline $\mathrm{B}-\mathrm{C}$ & 49 & 1 & 2 & 25 & $9: 3: 3: 1$ & 108.73 & $<0.001$ \\
\hline
\end{tabular}

${ }^{\mathrm{z}}$ Strain code: $\mathrm{A}=\mathrm{EK}-11, \mathrm{~B}=\mathrm{LB}-2, \mathrm{C}=\mathrm{SC}-4 \mathrm{~A}$.

${ }^{\mathrm{y}} \mathrm{RR}=$ resistant-resistant, $\mathrm{RS}=$ Resistant-susceptible, $\mathrm{SR}=$ susceptible-rcsistant, $\mathrm{SS}=$ susceptible-susceptible. 
The sizes of the 12 markers varied from 150 to $1400 \mathrm{bp}$ based on separation of RAPD amplification products on the agarose gels. A goodness-of-fit to $3: 1$ ratio for band presence to band absence for each of 12 markers was observed in $77 \mathrm{~F}_{2}$ plants (Table 4).

The integrated location of the gene loci for resistance to three $X c p$ strains and the loci of the 12 markers is shown in Fig. 2. A marker $\mathrm{U}_{10} 0_{400}$ showed no recombination with $\mathrm{U}_{20}{ }_{450}, \mathrm{~S} 12_{900}, \mathrm{Y} 4_{850}$, $\mathrm{F} 13_{1000}, \mathrm{P} 6_{1400}, \mathrm{Q} 1_{150}$, and Q11 1000 , indicating that the eight markers were observed at the same marker locus $\left(\mathrm{U}_{10} \mathrm{H}_{400}\right)$ in the linkage group (Fig. 2). A marker L $7_{750}$ showed no recombination with markers $\mathrm{U} 15_{300}$ and $\mathrm{P} 11_{400}$, suggesting that the three markers were observed at the same marker locus $\left(\mathrm{L}_{750}\right)$ (Fig. 2). A marker Y14 600 was also observed in the linkage group (Fig. 2). This linkage group included six loci spanning a length of $19.2 \mathrm{cM}$. All 12 markers showed coupling linkage with genes for
Fig. 1. The marker $\mathrm{U} 10_{400}$ expressing polymorphism between susceptible bulked DNA and resistant bulked DNA and between the susceptible parent (Nebr.\#4B) (S) and the resistant parent (CIAT-G40005) (R) to Xanthomonas campestris pv. phaseoli $(X c p) . \mathrm{P}_{1}=$ Nebr. \#4B $(\mathrm{S})$, $\mathrm{P}_{2}=$ CIAT-G40005 (R), SBD = susceptible bulked DNA to $X c p$ strain EK-11, RBD = resistan bulked DNA to Xcp strain EK-11, and $\mathrm{M}=$ molecular size marker. of interest because the frequency of recombination between the marker and the gene is low. Two markers - $\mathrm{L}_{750}$ and $\mathrm{U} 10_{400}$ - can be used effectively to select the genes for resistance to $X c p$ strains LB-2 and SC-4A, respectively. However, marker $L 7_{750}$ may be less effective in selecting the gene for resistance to $X c p$ strain EK-11 than a marker tightly linked to the gene.

Tagging different dominant genes for resistance to different $X c p$ strains with molecular markers may be useful in breeding common bean for enhanced resistance to $X c p$. Breeding lines with resistance to $X c p$, such as GN Nebraska \#1 sel. 27 (Coyne and Schuster, 1983), navy bean lines (Scott and Michaels, 1988), and XAN lines (McElroy, 1985), were derived from the interspecific crosses $P v$ (susceptible to $X c p) \times P a$ (resistant to $X c p$ ). It is suggested that the RAPD markers identified here could be more effective in transferring all of the resistance genes from the resistant tepary germplasm into moderately resistant or susceptible lines of common bean. Because of the low to intermediate

Table 4. The chi-square tests for a 3:1 segregation of RAPD bands for markers in an $\mathrm{F}_{2}$ tepary bean cross CIAT-G40005 [resistant to Xanthomonas campestris pv. phaseoli $(X c p)] \times$ Nebr.\#4B (susceptible to $X c p)$.

\begin{tabular}{|c|c|c|c|c|c|c|}
\hline \multirow{3}{*}{$\begin{array}{l}\text { RAPD } \\
\text { marker }\end{array}$} & \multicolumn{4}{|c|}{$\mathrm{F}_{2}$ plants (no.) } & \multirow[b]{3}{*}{$\chi^{2}$} & \multirow[b]{3}{*}{$P$} \\
\hline & \multicolumn{2}{|c|}{ Observed } & \multicolumn{2}{|c|}{ Expected } & & \\
\hline & Presence & Absence & Presence & Absence & & \\
\hline$\overline{\mathrm{U} 10_{400}{ }^{2}}$ & 49 & 28 & 58 & 19 & 4.72 & 0.04 \\
\hline $\mathrm{L} 7_{750}{ }^{\mathrm{y}}$ & 50 & 27 & 58 & 19 & 3.64 & 0.06 \\
\hline $\mathrm{Y} 14_{600}$ & 53 & 24 & 58 & 19 & 1.25 & 0.26 \\
\hline
\end{tabular}

${ }^{2}$ The marker $\mathrm{U} 10_{400}$ showed no recombination with the markers, $\mathrm{U} 20_{450}, \mathrm{~S} 12_{900}, \mathrm{Y}_{850}, \mathrm{~F} 13_{1000}, \mathrm{P} 6_{1400}, \mathrm{Q} 1_{150}$, and Q11 1000 .

${ }^{\mathrm{y}}$ The marker $\mathrm{L} 7_{750}$ showed no recombination with the markers, $\mathrm{U} 15_{300}$ and $\mathrm{P} 11_{400}$.

resistance to $X c p$. A marker $\mathrm{L7}_{750}$ was linked to the genes for resistance to $X c p$ strains EK-11 and LB-2 at $8.4 \mathrm{cM}$ and $2.4 \mathrm{cM}$, respectively. The gene for resistance to $X c p$ strain SC-4A was located between markers $\mathrm{U}^{10} \mathrm{H}_{400}$ and $\mathrm{Y} 14_{600}$ in the linkage group. Thus, markers $\mathrm{U} 10_{400}$ and $\mathrm{Y} 14_{600}$ were detected as flanking markers for the resistance gene to $X c p$ strain SC-4A at 2.4 and 7.2 $\mathrm{cM}$, respectively. These flanking markers would be more effective than a single linked marker in selecting the gene for resistance to $X c p$ strain SC-4A. The symbols $X c p-1, X c p-2$, and $X c p-3$ were assigned for the genes for resistance to $X c p$ strains EK-11, LB-2, and SC-4A, respectively. This is the first report on tagging major genes for resistance to $X c p$ in tepary bean.

Clusters of major genes controlling resistance to the same pathogen in a genomic region have been reported in lettuce by Anderson et al. (1996). Also reported were linked QTL and a major gene for resistance to two different fungal pathogens in peas and beans, respectively (Dirlewanger et al., 1994; Jung et al., 1996), linked QTL for resistance to a fungal and a bacterial pathogen in common bean (Jung et al., 1996), and QTL for reaction to Rhizobium and $X c p$ in common bean (Nodari et al., 1993). Early progenitors of present day plants may have evolved a common or nearly similar plant defense mechanisms. These genomic regions may have become more complex in the course of coevolution of the host and pathogen resulting in clustering of different genes for resistance.

A marker tightly linked to a gene can be used to select the trait narrow-sense heritabilities of the reaction to $X c p$ in $P v$ background (Coyne and Schuster, 1983), phenotypic selection is less effective. An $F_{1}$ embryo rescue method (Honma, 1956) along with the congruity backcross breeding method (Haghighi and Ascher, 1988) could be used to develop fertile $P v$ lines with the desired tagged resistance genes introgressed from tepary bean.

RAPD markers linked to QTL for resistance to Xcp in XAN-159 (Jung et al., 1997) and in BAC 6 (Jung et al., 1996) [the latter derived from resis-

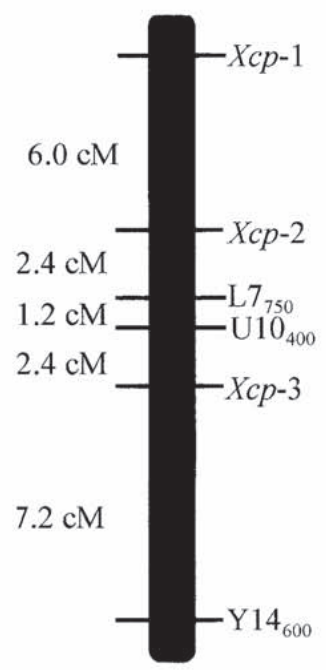
tance in GN Nebraska \#1 sel. 27 by Coyne and Schuster (1983)] were not linked to the major genes $X c p-1, X c p-2$, and $X c p-3$ for resistance in the $\mathrm{Pa}$ CIAT-G40005. The resistance to $X c p$ in BAT93 was mapped using RFLP markers (Nodari et

Fig. 2. A linkage group developed using three RAPD marker loci and three gene loci for resistance to three Xanthomonas campestris pv. phaseoli $(X c p)$ strains obtained from an $\mathrm{F}_{2}$ segregating population of the tepary bean cross. The gene and marker names are given on the right and the distance in $\mathrm{cM}$ is indicated on left side of a linkage group. $X c p-1=$ the gene for resistance to $X c p$ strain $\mathrm{EK}-11, X c p-2=$ the gene for resistance to $X c p$ strain LB-2, and $X c p-3=$ the gene for resistance to $X c p$ strain SC-4A. 
al., 1993), so their map cannot be compared. Using molecular markers linked to genes for resistance to $X c p$ could facilitate pyramiding of these different genes for resistance to $X c p$ from $P a$, along with other major genes from other germplasm to enhance the resistance of $P v$ and possibly to provide a more stable and durable resistance to $X c p$.

\section{Literature Cited}

Aggour, A.R. and D.P. Coyne. 1989. Heritability, phenotypic correlations, and associations of the common blight disease reactions in beans. J. Amer. Soc. Hort. Sci. 114:828-833.

Anderson, P.A., P.A. Okubara, R. Arroyo-Garcia, B.C. Meyers, and R.W. Michelmore. 1996. Molecular analysis of irradiation-induced and spontaneous deletion mutants at a disease resistance locus in Lactuca sativa. Mol. Gen. Genet. 251:316-325.

Andrus, C.F. 1948. A method of testing beans for resistance to bacterial blights. Phytopathology 38:757-759.

Arnaud-Santana, E., D.P. Coyne, K.M. Eskridge, and A.K. Vidaver. 1994. Inheritance; low correlations of leaf, pod, and seed reactions to common blight disease in common beans; and implications for selection. J. Amer. Soc. Hort. Sci. 119:116-121.

Claflin, L.E., A.K. Vidaver, and M. Sasser. 1987. MXP, a semiselective medium for Xanthomonas campestris pv. phaseoli. Phytopathology 77:730-734.

Coyne, D.P. and M.L. Schuster. 1983. Genetics of and breeding for resistance to bacterial pathogens in vegetable crops. HortScience 18:3036.

Dirlewanger, E., P.G. Isaac, S. Ranade, M. Belajouza, R. Cousin, and D. de Vienne. 1994. Restriction fragment length polymorphism analysis of loci associated with disease resistance genes and developmental traits in Pisum sativum L. Theor. Appl. Genet. 88:17-27.

Drijfhout, E. and W.J. Blok. 1987. Inheritance of resistance to Xanthomonas campestris pv. phaseoli in tepary bean (Phaseolus acutifolius). Euphytica 36:803-808.

Dursun, A. 1994. Inheritance of resistance to common bacterial blight within Phaseolus vulgaris L. and within Phaseolus acutifolius A. Gray crosses. MS thesis, Univ. of Nebraska, Lincoln.

Freytag, G.F. 1989. Inheritance of resistance to three strains of common bacterial blight (Xanthomonas campestris) in the cultivated tepary bean (Phaseolus acutifolius var. latifolius). Annu. Rpt. Bean. Improv. Coop. 32:101-102.

Haghighi, K.R. and P.D. Ascher. 1988. Fertile intermediate hybrids between Phaseolus vulgaris and $P$. acutifolius from congruity backcrossing. Sex. Plant Reprod. 1:51-58.

Haley, S.D., P.N. Miklas, J.R. Stavely, J. Byrum, and J.D. Kelly. 1993. Identification of RAPD markers linked to a major rust resistance gene block in common bean. Theor. Appl. Genet. 86:505-512.

Honma, S. 1956. A bean interspecific hybrid. J. Hered. 47:217-220.

Jung, G., D.P. Coyne, P.W. Skroch, J. Nienhuis, E. Arnaud-Santana, J. Bokosi, H.M. Ariyarathne, J.R. Steadman, J.S. Beaver, and S.M. Kaeppler. 1996. Molecular markers associated with plant architecture and resistance to common blight, web blight, and rust in common beans. J. Amer. Soc. Hort. Sci. 121:794-803.

Jung, G., P.W.Skroch, D.P. Coyne, J. Nienhuis, E. Arnaud-Santana, H.M. Ariyarathne, S.M. Kaeppler, and M.J. Bassett. 1997. Molecular-markerbased genetic analysis of tepary bean-derived common bacterial blight resistance in different developmental stages of common bean. J. Amer. Soc. Hort. Sci. 122:329-337.

Kelly, J.D. 1995. Use of random amplified polymorphic DNA markers in brecding for major gene resistance to plant pathogens. HortScience 30:461-465.

Kolkman, J.M. and T.E. Michaels. 1994. Major gene control of common bacterial blight in Phaseolus vulgaris. Annu. Rpt. Bean Improv. Coop. 37:73-74.

Kosambi, D.D. 1944. The estimation of map distances from recombination values. Ann. Eugenics 12:172-175.

Lander, E.S., P. Green, J. Abrahamson, A. Barlow, M.J. Daly, S.E. Lincoln, and L. Newburg. 1987. MAPMAKER: An interactive computer package for constructing primary genetic linkage maps with experimental and natural populations. Genomics 1:174-181.

McElroy, J.B. 1985. Breeding dry beans, Phaseolus vulgaris L., for common bacterial blight resistance derived from Phaseolus acutifolius A. Gray. PhD diss., Cornell Univ., Ithaca, NY.

Michaels, T.E. 1992. Genetic control of common blight resistance in lines derived from $P$, vulgaris/P. acutifolius crosses. Annu. Rpt. Bean Improv. Coop. 35:40-41.

Michelmore, R.W., I. Paran, and R.V. Kesseli. 1991. Identification of markers linked to disease resistance genes by bulked segregant analysis: A rapid method to detect markers in specific genomic regions using segregating populations. Proc. Natl. Acad. Sci. USA 88:9828-9832.

Miklas, P.N., J.R. Stavely, and J.D. Kelly. 1993. Identification and potential use of a molecular marker for rust resistance in common bean. Theor. Appl. Genet. 85:745-749.

Miklas, P.N., E. Johnson, V. Stone, J.S. Beaver, C. Montoya, and M. Zapata. 1996. Selective mapping of QTL conditioning disease resistance in common bean. Crop Sci. 36:1344-1351.

Nodari, R.O., S.M. Tsai, P. Guzman, R.L. Gilbertson, and P. Gepts. 1993. Toward an integrated linkage map of common bean. III. Mapping genetic factors controlling host-bacteria interactions. Genetics 134:341350 .

Park, S.O., D.P. Coyne, J.M. Bokosi, and J.R. Steadman. 1997. Identification of RAPD markers linked to a major gene for rust resistance and indeterminate growth habit using bulked segregant analysis in a common bean cross. Annu. Rpt. Bean Improv. Coop. 40:116-117.

Sacttler, A.W. 1989. Common bacterial blight, p. 261-283. In: H.F. Schwartz and M.A. Pastor-Corrales (eds.). Bean production problems in the tropics. Ctr. Intl, Agr. Trop., Cali, Colombia.

Schuster, M.L. and D.P. Coyne. 1981. Biology, epidemiology, genetics, and breeding for resistance to bacterial pathogens of Phaseolus vulgaris L. Hort. Rev. 3:28-57.

Schwartz, H.F. and G.E. Galvez. 1981. Bean production and pest constraints in Latin America, p. 3-14. In: H.F. Schwartz and G.E. Galvez (eds.). Bean production problems in the tropics. Ctr. Intl. Agr. Trop., Cali, Colombia.

Scott, M.E. and T.E. Michaels. 1988. Inheritance of resistance to common bacterial blight in common bean. Annu. Rpt. Bean Improv. Coop. 31:72. Scott, M.E. and T.E. Michaels. 1992. Xanthomonas resistance of Phaseolus interspecific cross selections confirmed by field performancc. HortScience 27:348-350.

Singh, S.P., C.Y. Munoz, W. Roca, and M.A. Pastor-Corrales. 1996. Breeding common bean for common bacterial blight resistance in the tropics. Proc. 1st Intl. Workshop of common bacterial blight of beans, Univ. of Puerto Rico, 19-21 Feb, P24-36.

Skroch, P. and J. Nicnhuis, 1995. Qualitative and quantitative characterization of RAPD variation among snap bean (Phaseolus vulgaris) genotypes. Theor. Appl. Genet. 91:1078-1085.

Williams, J.G.K., A.R. Kubelik, K.J. Livak, J.A. Rafalksi, and S.V. Tingey. 1990. DNA poly-morphisms amplified by arbitrary primers are useful as genetic markers. Nucleic Acids Res. 18:6531-6535.

Yoshii, K., G.E. Galvez, and G. Alvarez. 1978. Screening bean germplasm for tolerance to common blight caused by Xanthomonas phaseoli and the importance of pathogenic variation to varietal improvement. Plant Dis. Rpt. 62:343-347.

Zaiter, H.Z., D.P. Coyne, A.K. Vidaver, and J.R. Steadman. 1989. Differential reaction of tepary bean lines to Xanthomonas campestris pv. phaseoli. HortScience 24:134-137. 